\title{
Effects of inorganic and organic nutrient addition on a coastal microbial community (Isefjord, Denmark)
}

\author{
Stéphan Jacquet ${ }^{1, *}$, Harry Havskum $^{2, * *}$, T. Frede Thingstad ${ }^{3}$, Daniel Vaulot ${ }^{1}$ \\ ${ }^{1}$ Station Biologique, CNRS, INSU, Université Pierre et Marie Curie, BP 74, 29682 Roscoff Cedex, France \\ ${ }^{2}$ The International Agency for ${ }^{14} \mathrm{C}$ Determination, DHI, Agern Allé 11, 2970, Hørsholm, Denmark \\ ${ }^{3}$ Department of Microbiology, University of Bergen, Jahnebakken 5, 5020 Bergen, Norway
}

\begin{abstract}
Using flow cytometry (FCM), microbial populations were followed in a mesoscosm experiment manipulated with daily additions of mineral nutrients (as phosphates and nitrates in Redfield equilibrium), of degradable organic carbon (as glucose-C), or with the 2 treatments combined. Intensive sampling was performed in order to assess the short time-scale variability of the microbial community. Five autotrophic groups (including Synechococcus spp. and cryptophytes), 2 groups of heterotrophic bacteria, and 2 groups of viruses could be discriminated by FCM. The control enclosure (no addition) revealed that heterotrophic bacteria were carbon-limited. Synechococcus spp. abundance increased in the control, presumably because they experienced little competition from heterotrophic bacteria (which were C-limited) and from larger phytoplankton (which were not as efficient in nutrient uptake at low nutrient concentration and could not, therefore, sustain high growth rates). When $\mathrm{N}$ and $\mathrm{P}$ were added, however, larger-celled autotrophic populations were favoured. When glucose was added, alone or together with inorganic elements, the abundance of Synechococcus spp. and small eukaryotes was reduced, suggesting that, when released from C-limitation, heterotrophic bacteria are the best competitors for mineral nutrients. The addition of both inorganic and organic nutrients also enhanced cryptophytes in contrast to all other autotrophs, probably because of their heterotrophic capacity. Our results agree with recent evidence suggesting that heterotrophic bacteria are limited by both carbon and mineral nutrients, and demonstrate how this has important consequences for the success of their trophic neighbours in the microbial food web.
\end{abstract}

KEY WORDS: Carbon, Competition - Flow cytometry - Food web - Mesocosms - Picoplankton · Nutrients · Viruses

Resale or republication not permitted without written consent of the publisher

\section{INTRODUCTION}

Pelagic and coastal microbial ecosystems are characterised by a complex set of dynamic interactions between organisms. Competition for nutrients and light, commensalism between autotrophs and heterotrophic

Present addresses:

*Station INRA d'Hydrobiologie Lacustre, UMR CARRTEL, 75, Ave. de Corzent, BP 511, 74203 Thonon Cedex, France. E-mail: jacquet@thonon.inra.fr

${ }^{* *}$ Marine Biological Laboratory, University of Copenhagen, Strandpromenaden 5, 3000 Helsingør, Denmark bacteria, recycling of material, cell lysis and predation are typical processes implicated in the ecological interactions between viruses, bacteria, micro-algae and their predators. Trophic interactions occur from 'top to bottom' (protozoan grazing and viral control) and from 'bottom to top' (resource availability: nutrients, amount of prey). These interactions are primarily responsible for population structure and diversity, and they operate simultaneously rather than separately (Thingstad et al. 1997).

Until recently, many studies have concluded that bacterial and primary productions are well correlated, the former being generally dependent on the latter, 
according to the general scheme that bacterial production is sustained by the flow of organic matter produced by the phytoplankton (Cole et al. 1988 and references therein). Using a more theoretical approach, it has been shown that relatively simple food web models, incorporating both predation and competition for mineral nutrients, can exhibit 2 types of steady states characterised by a limitation of the growth rate of heterotrophic bacteria by degradable organic-C or mineral nutrients, respectively (Thingstad et al. 1997). This leads to a more subtle picture of the relationship between nutrient loading, phytoplankton and bacteria than the empirical observation 'more phytoplanktonmore degradable dissolved organic matter (DOM) more bacterial production'. This theory seems able to explain the main dynamical features in experimental systems in which natural pelagic communities are manipulated with the addition of organic and inorganic nutrients (Thingstad et al. 1999). One inherent problem in this theory, however, is the following: why do bacteria not outcompete phytoplankton when limited by the same mineral nutrient (Currie \& Kalff 1984)? This can be resolved by incorporating selective predation on the superior competitor, in this case assumed to be the heterotrophic bacteria (Thingstad et al. 1998). The outcome in terms of biomass distribution between competing organisms is thus not explainable by competitive abilities alone, but has to incorporate the effect of predation. Since prey size is normally believed to be a main factor determining predator selectivity (Gonzales et al. 1990), the coexistence of the small autotrophic picoplankton and heterotrophic bacteria (autotrophic picoplankton approach, and to some extent overlap, heterotrophic bacteria in size) is particularly intriguing.

Coastal and pelagic ecosystems share the presence of an active picoplankton community that includes cyanobacteria, eukaryotic algae, heterotrophic bacteria (Azam et al. 1983, Li \& Platt 1987) and viruses (Bergh et al. 1989). Coastal ecosystems are characterised by continuous or sporadic nutrient inputs (both inorganic and organic) that favour the occurrence of populations of large cells such as diatoms. These ecosystems display a cascade of trophic relationships and an efficient transfer of matter towards higher trophic levels (Rivkin et al. 1996). In this context, the smaller size class of the plankton (the picoplankton) is viewed as a 'background' group in enriched coastal systems, although it may dominate these systems under nutrient-depleted conditions (Agawin et al. 2000). The expected response to increased nutrient input is therefore an increase in biomass of the larger sized phytoplankton, i.e. of the size class for which the time scale of predator response is long (of the order of a week to a month). This was demonstrated experimentally in open-ocean waters during the Ironex II experiment (see for example Cavender-Bares et al 1999).

Unfortunately, data on the response of the picoplankton community are still very scarce (Ypma \& Throndsen 1996). Open-field studies suffer from inherent problems with experimental manipulation, as well as from difficulties in interpreting population changes in drifting water masses. Hence, mesocosms, although not perfect representations of natural ecosystems because of their ecological inertia and resilience (Egge \& Heimdal 1994), constitute an interesting alternative to field measurements to study various phenomena occurring in the marine environment such as pollution, effect of herbicides and pesticides, and/or trophic relationships (Berg et al. 1999 and references therein).

During a field workshop in Isefjord waters (Denmark) in June 1998, a mesocosm study was conducted using $3 \mathrm{~m}^{3}$ enclosures in order to investigate the response of the microbial food web structure to daily addition of phosphorus, nitrogen and carbon. An effort was made to sample several times a day to investigate short time-scale variability in population abundance and some cellular parameters (e.g. scatter and chlorophyll fluorescence) measured by flow cytometry. This strategy enabled us to investigate the following: what are the effects of both inorganic and organic nutrient addition on photosynthetic organisms vs heterotrophic bacteria competition within a coastal microbial community?

\section{MATERIALS AND METHODS}

Study site and experimental set up. The mesocosm enrichment experiment was conducted in a coastal embayement of the Isefjord, located in the central eastern part of Denmark (55 $42^{\prime} \mathrm{N}, 11^{\circ} 48^{\prime} \mathrm{E}$ ) from 16 to 26 June 1998. Enclosures consisted of large nylon-armed natural polyethylene bags (Monarfold, Fjordblink Plast Industries, Randers, Denmark), $3 \mathrm{~m}$ in length (straight down) and $1.25 \mathrm{~m}$ in diameter at the top. On 15 June, $1 \mathrm{~d}$ before the beginning of the experiment, they were

Table 1. Experimental design summary. Nutrients were added daily to each enclosure to obtain final concentrations shown. $\mathrm{N}+\mathrm{P}+10 \mathrm{C}$ corresponds to a 10 times carbon excess compared to the Redfield ratio

\begin{tabular}{|ccccc|}
\hline \multirow{2}{*}{ Enclosure } & Added & \multicolumn{4}{c|}{ Final concentration $(\mu \mathrm{M})$} \\
& nutients & $\mathrm{NaNO}_{3}$ & $\mathrm{KH}_{2} \mathrm{PO}_{4}$ & $\mathrm{C}_{6} \mathrm{H}_{12} \mathrm{O}_{6}$ \\
\hline 1 & $+\mathrm{N}+\mathrm{P}$ & 1.6 & 0.1 & - \\
4 & $+\mathrm{N}+\mathrm{P}+10 \mathrm{C}$ & 1.6 & 0.1 & 106.0 \\
9 & Nothing & - & - & - \\
11 & $+10 \mathrm{C}$ & - & - & 106.0 \\
\hline
\end{tabular}



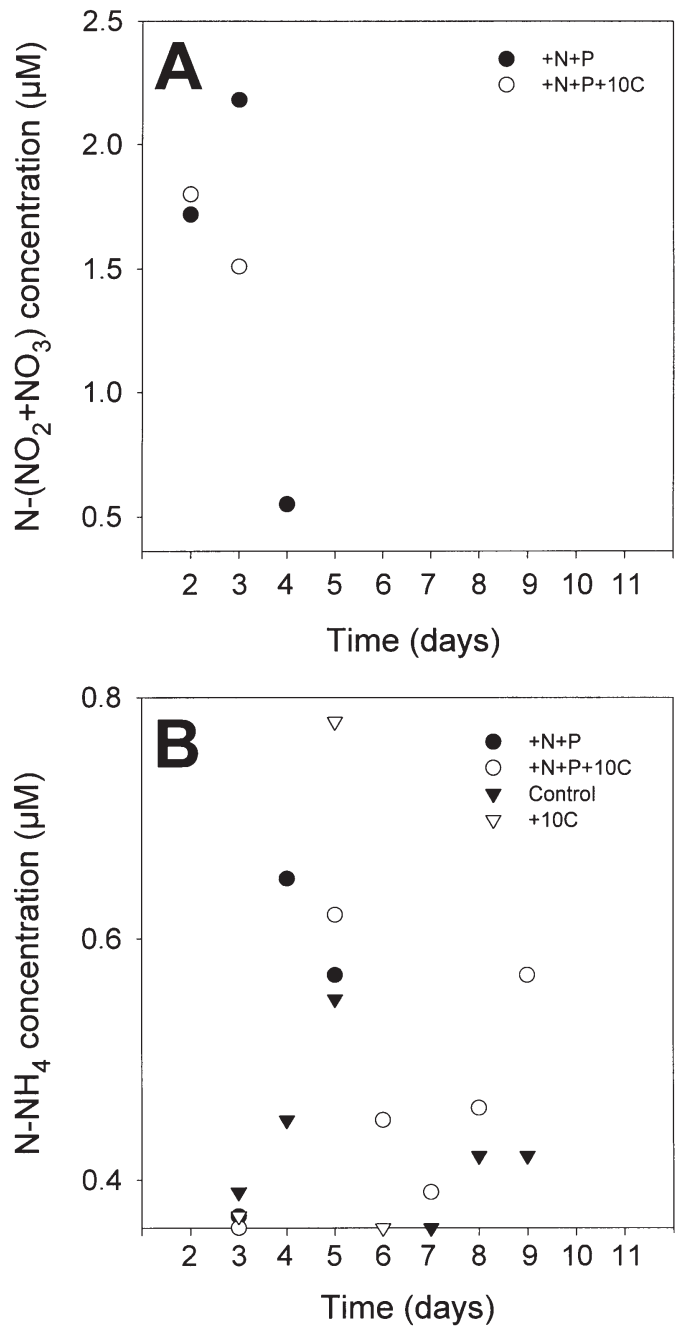

Fig. 1. Evolution of nutrient concentration. Nutrient additions and measurements were performed once daily. P was never detected (limit of detection $0.16 \mu \mathrm{M}$ ); the threshold of detection for $\mathrm{N}$ was $0.36 \mu \mathrm{M}$. (Data kindly provided by Rita Muchitsch)

filled with approximately $3 \mathrm{~m}^{3}$ of fjord water sampled $70 \mathrm{~m}$ from the coast (water depth $3.5 \mathrm{~m}$ ). Water-column homogeneity inside the bags was ensured by an air-lift system (e.g. Egge \& Heimdal 1994). Metallic scarecrows were installed at the top of each enclosure to prevent the introduction of faeces from perching birds.

Nutrient enrichment. The combinations of nutrient concentrations used in this study are summarised in Table 1. Enrichments began in the evening of 16 June and were performed daily between 21:00 and 22:00 $\mathrm{h}$ (local time). Nutrient concentrations were measured daily (Fig. 1) from samples taken between 9:00 and 10:00 h.

Physical and environmental parameters. Water parameters (temperature, salinity, and oxygen concentration) were measured every day in all enclosures using a multiparameter water-quality monitor (600 XL-200-M, Endeco/YSI, OH, USA). Weather parameters such as wind, irradiance level, cloud cover and rainfalls were also monitored (not shown). The length of the day was about $18 \mathrm{~h}$ (sunrise at 4:00 to 4:30 h and sunset at 22:00 to $22: 30 \mathrm{~h}$ ).

Sampling strategy. Sampling was performed on average 7 times a day (except for the first day) during the first week (between 16 and 19 June), and 10 to 11 times a day during the second week (between 20 and 26 June). The sampling interval was about 3 to $4 \mathrm{~h}$, and $2 \mathrm{~h}$ during the first and the second weeks, respectively. A small volume of water (about $10 \mathrm{ml}$ ) was sampled $0.4 \mathrm{~m}$ under the surface and in the central part of the bag near the water flow created by the air-mixing system.

Flow cytometry sample-processing and analysis. Samples were fixed with a mixture of glutaraldehyde and paraformaldehyde $(0.05$ and $1 \%$ final concentration, respectively: see Jacquet et al. 1998) for $15 \mathrm{~min}$ in subdued light conditions and then frozen in liquid nitrogen. Back at the laboratory, they were kept at $-80^{\circ} \mathrm{C}$ until flow cytometry (FCM) analysis with a FACSort instrument (Becton Dickinson, San Jose, CA, USA). FCM analyses of autotrophs, heterotrophic bacteria and viruses were performed as described in Marie et al. (1999, 2000). Autotrophic populations were discriminated on the basis of their forward- and rightangle light scatters (FALS and RALS), chlorophyll (chl) fluorescence and phycoerythrin (PE) fluorescence when available (Fig. 2A,B). Heterotrophic bacteria and viruses were stained using the nucleic acid dye SYBR Green I (see Marie et al. 1999) and discriminated on the basis of their FALS and RALS vs their green-DNA fluorescence (Fig. 2C,D,E). All cellular parameters were normalised to the values measured for $0.95 \mu \mathrm{m}$ beads. Data were collected in listmode files and then analysed using CYTOWIN (Vaulot 1989, available at www.sb-roscoff.fr/Phyto/cyto.html).

Confocal microscopy analysis. Some samples were observed using confocal laser scanning microscopy (CLSM, Fluoview, Olympus Optical Co., Tokyo, Japan) in order to identify some specific groups such as the large elongated bacteria (see below) and to measure cell size of the heterotrophic bacterial community. Samples were filtered onto $0.2 \mu \mathrm{m}$ pore-size inorganic membrane filters (Anodisc, Whatman ${ }^{\mathrm{TM}}$, Maidstone, UK). The filter was placed onto a slide. A $20 \mu \mathrm{l}$ mixture (50 to $50 \%$ ) of PBS (phosphate buffer saline, Sigma) and bi-distilled glycerol ( $\mathrm{d}=1.26$, Fisher Scientific, Elancourt, France) was added with a drop of SYBR green I (1/1000 final concentration). A $22 \times 40 \mathrm{~mm}$ coverslip was overlaid on preparation. Images were acquired with the Fluoview software and the cell size of the bacteria was computed using Image Tools (T. Wilcox, Version 1.27, available at www.uthscsa.edu/dig/download.html). 
Biomass estimation. Bacterial size, determined by confocal microscopy and image analysis, allowed us to convert cell number to biomass using the conversion factor of $20 \mathrm{fgC} \mathrm{cell}^{-1}$ (Lee \& Furhman 1987) for hetero- trophic picobacteria ranging between 0.4 and $0.5 \mu \mathrm{m}$ in diameter, and a factor of $53 \mathrm{fgC} \mathrm{cell}^{-1}$ for large elongated bacteria (Simon \& Azam 1989). Average cell volumes for Synechococcus spp. and cryptophytes were
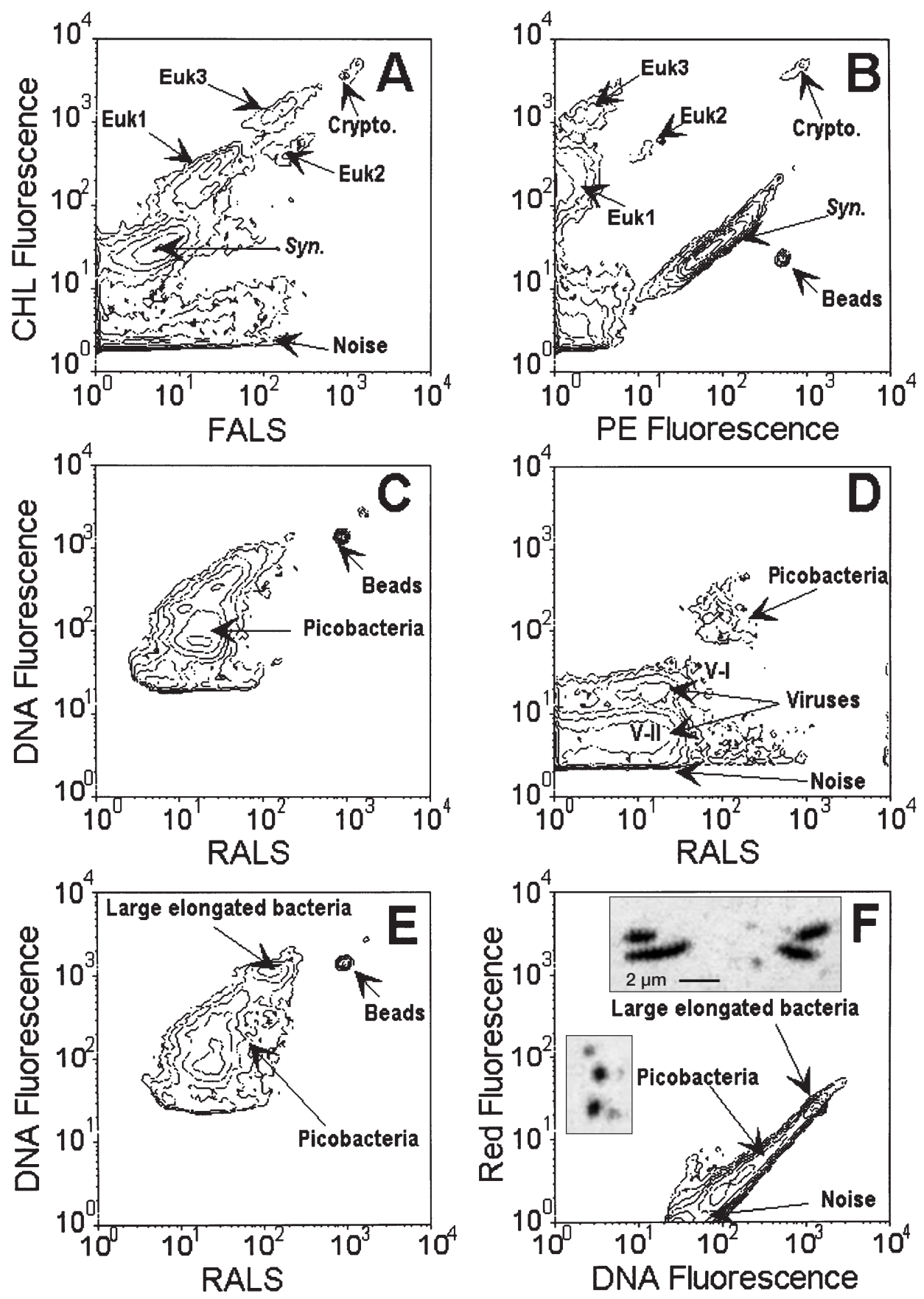

Fig. 2. Flow cytometric analysis of natural populations sampled in Enclosure 1 (09:00 h, 20 June 1998). On unstained samples, Synechococcus spp., cryptophytes and eukaryotic algae (Syn., Crypto., Euk1, 2 and 3, respectively) were discriminated on the basis of forward angle light scatter (FALS) vs chlorophyll red fluorescence (A) or phycoerythrin orange fluorescence (B). On samples stained with the DNA dye SYBR Green I, picobacteria (C) and Viruses V-I and V-II (D) were discriminated on the basis of the green DNA-dye complex fluorescence vs right-angle light scatter (RALS). Large elongated bacteria were discriminated on the same basis (E), using red vs green DNA fluorescence to verify they were not autotrophic cells (F). Insets on panel (F) correspond to photos obtained with the confocal microscope, illustrating both pico- and large elongated bacteria after staining with SYBR green 
determined from 100 individual measurements and were converted to cell carbon (pg) using conversion

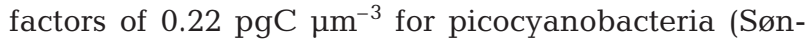

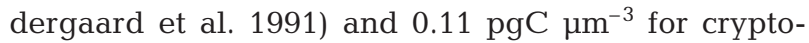
phytes (Mullin et al. 1966). A value of $2108 \mathrm{fgC} \mathrm{cell}^{-1}$ was used for other eukaryotic algae (Verity et al. 1992). For viruses, a carbon content of $0.08 \mathrm{fgC}$ virus $^{-1}$ was used according to Bratbak et al. (1992), assuming that most viruses had a mean size of $60 \mathrm{~nm}$, a density of 1.4, and a carbon content of $50 \%$.

Net growth rate estimation. Net growth rate $(\mu)$ was estimated from cell numbers as follows:

$$
\mu=\frac{\ln \left[N\left(t_{2}\right) / N\left(t_{1}\right)\right]}{\left(t_{2}-t_{1}\right)}
$$

where $N\left(t_{1}\right)$ and $N\left(t_{2}\right)$ are the average values $(\mathrm{n}=2)$ of the population at the beginning $\left(t_{1}\right)$ and the end $\left(t_{2}\right)$ of a $24 \mathrm{~h}$ sampling period (early morning), when no division occurs (as judged from the FCM signals).

\section{RESULTS}

\section{Hydrographic parameters and nutrient evolution}

Patterns recorded for temperature were similar in all enclosures during the course of the experiment (data not shown). Temperature increased on average from 14.5 to $18^{\circ} \mathrm{C}$ throughout the period of study. Salinity changed very little, (between 21.2 and 21.7 PSU), as a result of balance between evaporation and precipitation (data not shown). From 16 to 21 June, there was an important increase in oxygen saturation in all the enclosures from $70-73 \%$ to $100-115 \%$. Subsequently, oxygen decreased slightly for the $+\mathrm{N}+\mathrm{P}$-treated enclosure and more strongly in the other bags. The decrease was especially marked in the $+\mathrm{N}+\mathrm{P}+10 \mathrm{C}$-treated bag (data not shown). Despite the daily additions, all the enclosures were depleted in $\mathrm{PO}_{4}$ (concentrations always below the threshold of detection). $\mathrm{NO}_{2}+\mathrm{NO}_{3}$ was detected at $\mu \mathrm{M}$ levels in the enclosures that received $+\mathrm{N}+\mathrm{P}$ additions for the first $3 \mathrm{~d}$ only (Fig. 1A). The presence of $\mathrm{NH}_{4}$, ranging from 0.1 to $0.8 \mu \mathrm{M}$, was detected in all bags from Day 3, but disappeared rapidly in both $+\mathrm{N}+\mathrm{P}$ and $+10 \mathrm{C}$ enclosures at Days 5 and 6 respectively, in contrast to what was observed in the other 2 bags (Fig. 1B).

\section{Microbial diversity}

Five autotrophic populations could be discriminated by FCM (Fig. 2A,B). Among these autotrophs, 2 populations displayed strong orange fluorescence, most likely due to phycoerythrin. The population with the smaller scatter had a typical Synechococcus (cyanobacterium) signature. We verified by epifluorescence microscopy (EFM) following flow cytometry sorting that the larger population was composed of cryptophytes and not of large cyanobacteria as reported in the equatorial Pacific Ocean by Neveux et al. (1999). The same approach did not allow us to identify other eukaryotic populations. However, other data suggest that they were most likely prymnesiophytes, prasinophytes and dinoflagellates (see 'Discussion'). These 3 populations were named Euk1, Euk2 and Euk3 (Fig. 2A). On Day 3, we observed a population of heterotrophic bacteria with higher light scatter and DNA fluorescence (Fig. 2C,E,F) than the picobacteria present in the original seawater community. FCM sorting and EFM observation suggested that these cells were large elongated bacteria. Average picobacteria cell diameter was about $0.5 \mu \mathrm{m}(\mathrm{SD}=0.14, \mathrm{n}=194)$, whereas the length of large bacteria was about $2.3 \mu \mathrm{m}$ on average ( $\mathrm{SD}=0.5, \mathrm{n}=9$, Fig. 2F: top inset). We observed 2 distinct populations of viral particles (Fig. 2D), named V-I and V-II following Marie et al. (1999).

\section{Synechococcus spp.}

At the beginning of the experiment, the Synechococcus spp. concentration was about $5 \times 10^{4}$ cells ml ${ }^{-1}$. In all enclosures, an identical decrease in concentration was recorded between the first and the second days. Subseqently, each treatment induced a specific pattern. In the control, a clear and regular increase in cell concentrations was observed throughout the experiment (Fig. 3A). Cell numbers displayed a diel pattern with minimum and maximum concentrations recorded around 12:00 and 24:00 h, respectively. Average net growth rate was about 0.2 to $0.3 \mathrm{~d}^{-1}$ over the study period. Relative values of chl fluorescence and RALS decreased significantly between the start of the experiment and the beginning of the second week (Fig. 3B,C). The addition of inorganic $+\mathrm{N}+\mathrm{P}$ resulted in a bellshaped pattern for cell number. During the period of increase, maximum net growth rate was about $0.54 \mathrm{~d}^{-1}$ (2-fold higher than in the control). Maximum concentration was reached on Day 6, followed by a steady decrease. Both RALS and chl fluorescence increased significantly compared to the control during the first few days, but thereafter returned to control values (Fig. 3D,E). Addition of $+\mathrm{N}+\mathrm{P}+10 \mathrm{C}$ or of $10 \mathrm{C}$ alone resulted in only weak variations in cell abundance and poorly defined diel patterns compared to the 2 previous treatments (Fig. 3A). With $+\mathrm{N}+\mathrm{P}+10 \mathrm{C}$, Synechococcus spp. cell concentration increased slightly for about $4 \mathrm{~d}$, and then dropped and stabilised. With $+10 \mathrm{C}$ addition 

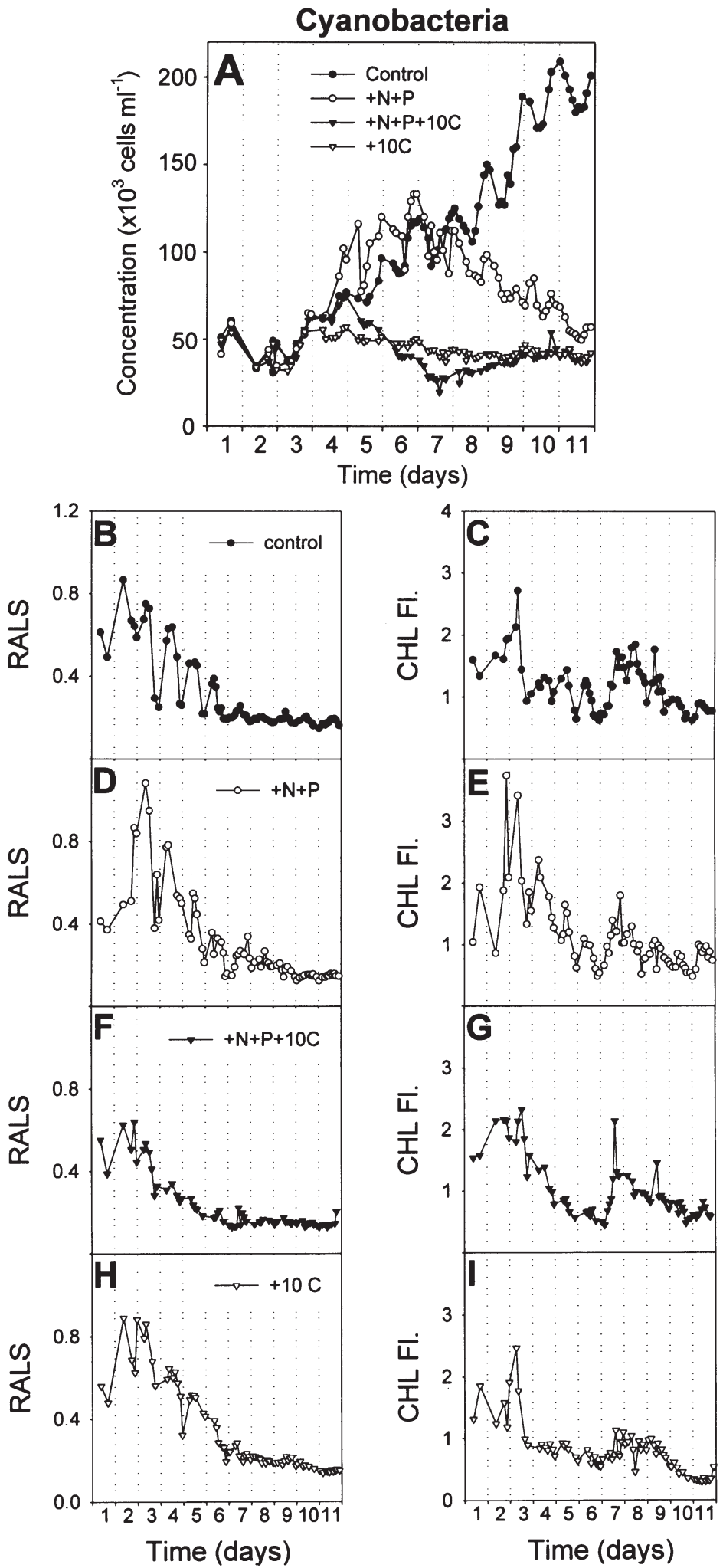

Fig. 3. Time series for Synechococcus abundance (A), RALS (B,D, $\mathrm{F}, \mathrm{H})$ and chlorophyll fluorescence $(\mathrm{C}, \mathrm{E}, \mathrm{G}, \mathrm{I})$ between 16 and 26 June in the control $(\bullet)$ and in the 3 different enclosures that received $+\mathrm{N}+\mathrm{P}(\mathrm{O}),+\mathrm{N}+\mathrm{P}+10 \mathrm{C}(\mathbf{\nabla})$ and $+10 \mathrm{C}(\nabla)$ alone, Synechococcus spp. concentration decreased very slowly throughout the experiment (Fig. 3A).

\section{Cryptophytes and other eukaryotic algae}

The initial concentration of cryptophytes was about $1.1 \times 10^{3}$ cells $\mathrm{ml}^{-1}$. Two different patterns were recorded for this group. Both in the control and in the enclosure that only received carbon $(+10 \mathrm{C})$, a steady decrease in the concentration was recorded throughout the experiment (Fig. 4A). In contrast, for enclosures that received $+\mathrm{N}+\mathrm{P}$ (with or without $\mathrm{C}$ ), cell concentration increased during the first week and then decreased

(Fig. 4A). Maximum net growth rate in the initial period was about $0.32 \mathrm{~d}^{-1}$, i.e. lower than for Synechococcus spp. $\left(\mu=0.54 \mathrm{~d}^{-1}\right)$. The addition of $\mathrm{C}$ resulted in a lower maximal abundance as well as a faster decrease compared to $\mathrm{N}$ and $\mathrm{P}$ addition alone. All the other eukaryotic populations (Euk1, 2 and 3) had similar behaviours, with the sole addition of $+\mathrm{N}+\mathrm{P}$ causing a significant and rapid increase in abundance (Fig. 4). Under these conditions, Euk1, 2 and 3 had net maximum growth rates of $0.46,0.41$ and $0.7 \mathrm{~d}^{-1}$, repectively. In the other treatments, including the control, there was a clear decrease in the concentration of Euk1 during the first part of the experiment that was followed by a moderate increase during the second part. This increase was particularly marked in the $+10 \mathrm{C}$ treatment, with a net growth rate of about $1.1 \mathrm{~d}^{-1}$ between Days 7 and 8 (Fig. 4B). Euk2 and Euk3 had quite parallel behaviours in the other treatments (i.e. excluding $+\mathrm{N}+\mathrm{P}$ alone). In particular, after relative stability until Day 7 , they increased markedly in the control. Euk3 cells also increased in the bag with carbon addition, but only at the very end of the experiment.

\section{Heterotrophic bacteria and viruses}

Initial picobacteria concentration was about $5 \times$ $10^{6}$ cells $\mathrm{ml}^{-1}$. In all enclosures, with or without nutrient addition, picoheterotrophic bacterial biomass increased very slowly during the first $7 \mathrm{~d}$ (Fig. 5A). The $+\mathrm{N}+\mathrm{P}+10 \mathrm{C}$ treatment was characterised by a marked increase in picobacteria, with maximum concentration reaching $25 \times 10^{6}$ cells $\mathrm{ml}^{-1}$ and the net growth rate about $0.66 \mathrm{~d}^{-1}$. In this enclosure, the concentration of picobacteria dropped very quickly during the last $2 \mathrm{~d}$. Large elongated bacteria were only detected in the enclosure receiving both inorganic and organic enrichments $(+\mathrm{N}+\mathrm{P}+10 \mathrm{C})$. Their concentration in- 

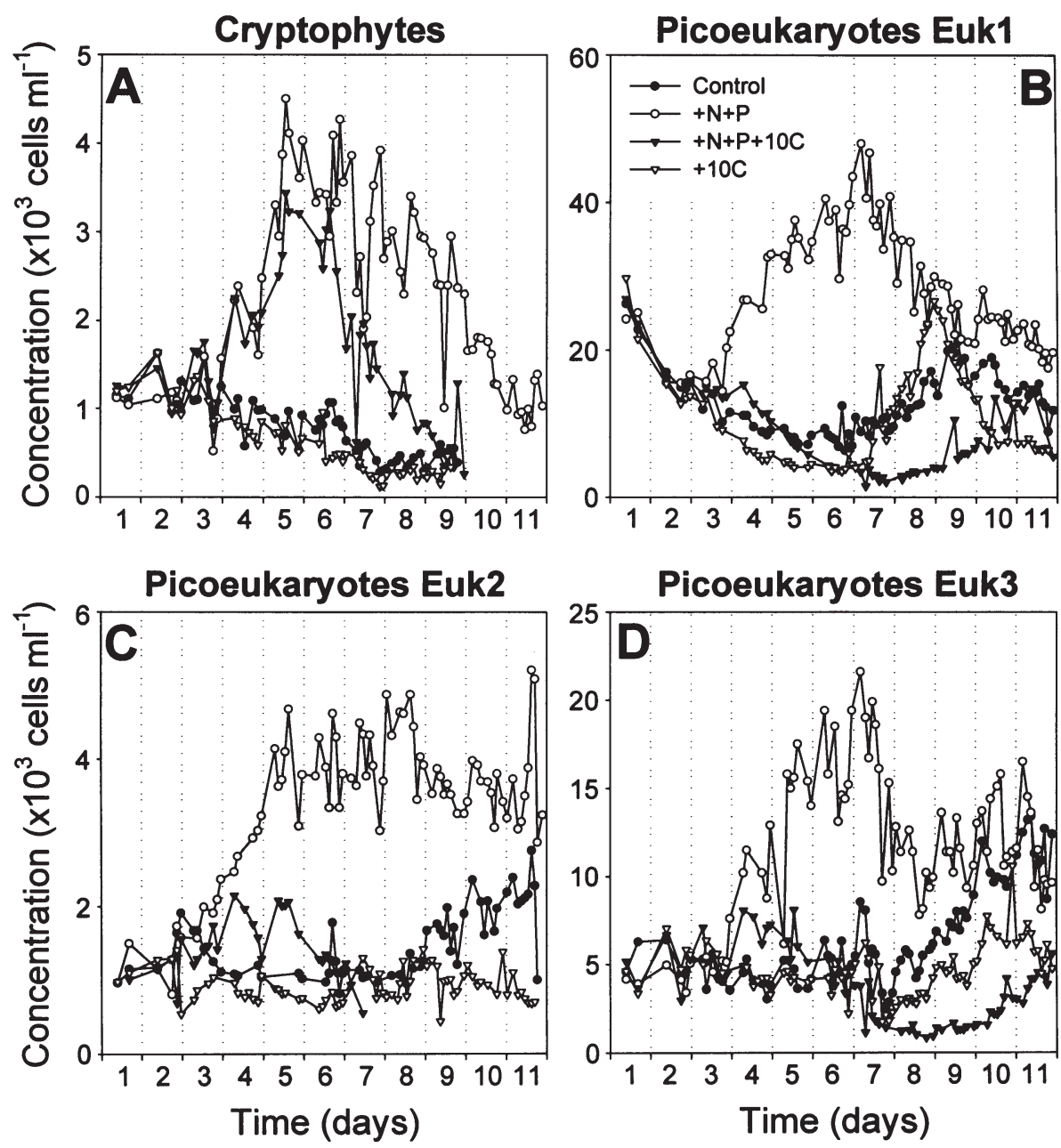

Fig. 4. Time series for abundance of cryptophytes (A) and the other eukaryotic populations Euk1 (B), Euk2 (C) and Euk3 (D) between 16 and 26 June in the 4 enclosures. Symbols as in Fig. 3

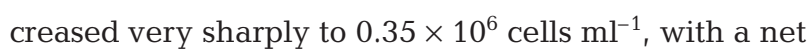
growth rate of $0.66 \mathrm{~d}^{-1}$ (Fig. 5B). These bacteria abruptly fell below FCM detection after Day 5. Virus concentration was in excess of $>2 \times 10^{8}$ particles $\mathrm{ml}^{-1}$ at the end of the experiment. The concentration of V-I, i.e. viruses with the higher green DNA fluorescence (Fig. 2D), was always 1 order of magnitude lower than that of V-II. While V-II viruses did not display any marked differences with any of the additions used, V-I viruses increased markedly towards the end of the experiment, especially in the $+\mathrm{N}+\mathrm{P}+10 \mathrm{C}$ enclosure.

\section{Integrated carbon biomass}

The contribution to biomass in terms of carbon (averaged over the diurnal period) was estimated for each group in all enclosures on Days 1, 6 and 10 (Fig. 6).
Except for the $+\mathrm{N}+\mathrm{P}$-treated bag, picobacteria were always the major contributors to total carbon biomass. In the control and $+10 \mathrm{C}$ enclosure, total picoplankton biomass was nearly constant throughout the experiment, varying only from 150 to $195 \mu \mathrm{gC}^{-1}$. In contrast, with the $+\mathrm{N}+\mathrm{P}$ treatment, biomass clearly increased between Days 1 and 6 from 194 to $286 \mu \mathrm{gC} \mathrm{l}^{-1}$ due to eukaryotic algae, and then levelled off with no further increase. The biomass increase was more marked in the enclosure receiving both inorganic and organic nutrients. It took place mainly during the second part of the experiment, and could be attributed to heterotrophic bacteria (more than $90 \%$ of the total biomass). The integrated carbon biomass for large elongated bacteria on Day 5 for the $+\mathrm{N}+\mathrm{P}+10 \mathrm{C}$ enclosure was about $16 \mu \mathrm{gC} \mathrm{l}^{-1}$, representing only a tiny fraction of the total picoplankton biomass.

\section{DISCUSSION}

\section{General conditions}

Environmental parameters (salinity, temperature) did not vary between enclosures and therefore were unlikely to have influenced the general behaviour of the different populations. Inorganic nutrients remained at low or undetectable (P) levels. Although nitrate is generally considered to limit primary production in most of the world oceans, it has recently been increasingly suggested that $\mathrm{P}$ is a key limiting nutrient in both coastal and pelagic waters (Thingstad et al. 1998, Karl 1999). This situation seems common in transition zones such as estuaries (Lee et al. 1996) and freshwater-influenced fjords (Thingstad et al. 1993) in particular, due to the combined effects of $\mathrm{P}$ removal in sewage treatment plants and nitrate runoff from excess farmland fertilisation. This was probably the case here, with a sewage treatment plant in the city of Holbaek $(<10 \mathrm{~km}$ from the study site) and farmland surrounding the Isefjord. Carbon was clearly co-limiting with inorganic elements for heterotrophic bacterial growth, as suggested by the patterns recorded for both pico- and large elongated bacteria cell numbers (see later subsection). 

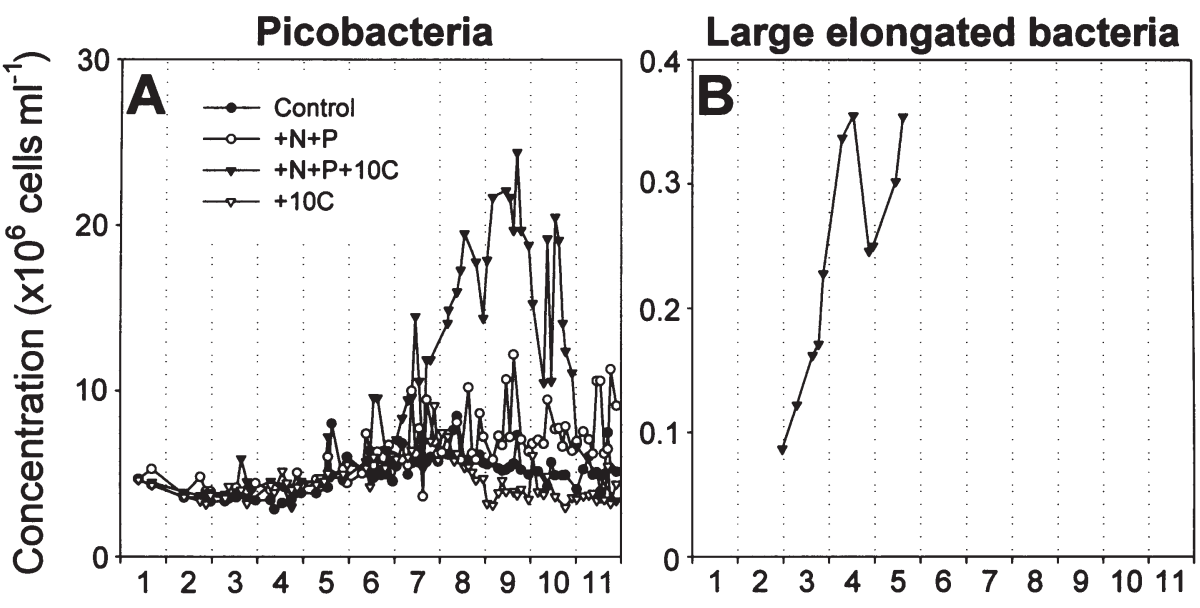

a common feature in temperate coastal systems (Havskum \& Riemann 1996, Havskum \& Hansen 1997). Comparison with estimates made by EFM (data not shown) indicate that Euk1 and 3 probably correspond to prasinophytes and prymnesiophytes, respectively. Within the bacterial community, FCM discriminated unambiguously 2 groups. Picobacteria concentration, about $5 \times$ $10^{6}$ cells $\mathrm{ml}^{-1}\left(\sim 100 \mu \mathrm{gC} \mathrm{l}^{-1}\right)$, was slightly higher than previous records for the Bay of Aarhus (Havskum \& Riemann 1996), but compared well to a variety of other surface and coastal habitats in summer (e.g. Li 1998 and references therein). Two populations of free viruses were detected based on their green emission of the complex DNA-SYBR Green I. They were referred to as V-I and V-II following Marie et al. (1999). The general dynamics recorded for the 2 groups and the picoplankters (see following subsection) suggest that V-I and V-II might infect bacteria and small eukaryotes, respectively, as previously suggested by Marie et al. (1999). Indeed, V-I displays the same relative green fluorescence intensity after staining as do viruses from some eukaryotic algae (Brussaard et al. 1999). V-II is 10-fold more abundant than V-I, a ratio commensurate with the ratio of heterotrophic bacte-

\section{Initial structure of the food web}

The Synechococcus spp. concentration, about $50 \times$ $10^{3}$ cells $\mathrm{ml}^{-1}$, was slightly higher than that reported further north (both at Oslofjord and Skagerrak) by Ypma \& Throndsen (1996) at the same period of the year, but globally similar to concentrations observed in temperate surface waters in summer (e.g. Waterbury et al. 1986). Compared to the other bacteria, the carbon biomass contribution of Synechococcus spp. was low $(\sim 5 \%)$. The contribution of cryptophytes to total plankton biomass $<5 \mu \mathrm{m}$ was also small $\left(<5 \%\right.$ with $\sim 10^{3}$ cell $\mathrm{ml}^{-1}$ ), as previously reported for the same region (Bay of Aarhus) by Havskum \& Riemann (1996). Among the eukaryotic algae $<10 \mu \mathrm{m}$, dinoflagellates, prymnesiophytes and prasinophytes were probably the dominant classes according to observations using epifluorescence (EFM) microscopy (Havskum et al. unpubl. data), ria to phytoplankton in natural samples. The initial concentrations of viruses in the enclosures were very similar to values obtained for coastal waters during the most productive part of the year (Bratbak et al. 1994). The estimated contribution of viruses to total microbial carbon $\left(\sim 10 \mu \mathrm{gC}^{-1}\right)$ could not be ignored, and indeed exceeded that of Synechococcus spp.

\section{Food web dynamics}

The control enclosure provides information about the dynamics of the microbial food web left to itself without an external nutrient supply. Synechococcus spp. were the only group to increase significantly throughout the experiment period. Net growth rate (estimated in the control to be 0.2 to $0.3 \mathrm{~d}^{-1}$ ) was similar to that calculated further north by Ypma \& Throndsen (1996) at the same 
period of the year. In temperate waters, Synechococcus spp. biomass appears to be well correlated with temperature and solar irradiance increases at the seasonal scale (Waterbury et al. 1986, Ypma \& Throndsen 1996). Enclosing the populations in bags increased the average light level experienced by the cells (not shown). This could be inferred from cellular changes recorded for Synechococcus spp. (Fig. 3). The chlorophyll fluorescence increase during the first $2 \mathrm{~d}$ probably reflects
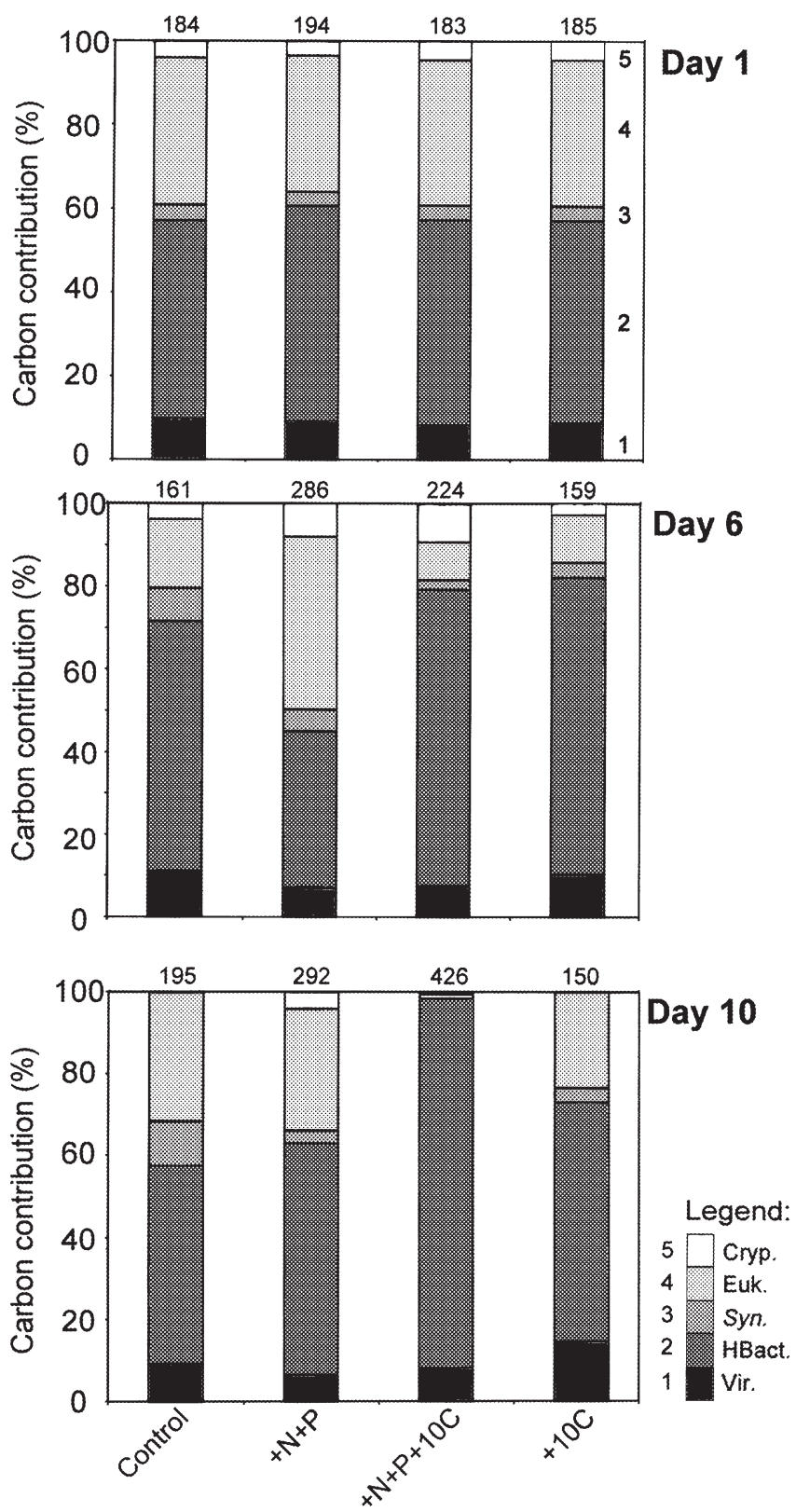

Fig. 6. Carbon contribution in percentage of the cyanobacteria, heterotrophic picobacteria, eukaryotic algae, cryptophytes and viral communities on Days 1, 6, and 10 of the experiment for each enclosure. Values above each bar are the corresponding total carbon amount for each treatment in $\mathrm{\mu g} \mathrm{l}^{-1}$ an increase in cellular pigment concentration in response to nutrient enrichment (see Cavender-Bares et al. 1999 and references therein). However, after that, chl fluorescence slowly decreased, although population concentrations displayed significantly different behaviours in response to nutrient additions. This drop was most probably due to acclimation to high irradiance (Olson et al. 1990), because cells were maintained near the surface in the $3 \mathrm{~m}$-deep mesocoms, whereas in the fjord, vertical mixing processes entrain them deeper. Comparison of net growth rates during the first few days of the experiment, between the control and the $+\mathrm{N}+\mathrm{P}$ enclosure, revealed that inorganic nutrients in Isefjord waters were limiting even for Synechococcus spp. growth (e.g. $0.54 \mathrm{~d}^{-1}$ in $+\mathrm{N}+\mathrm{P}$ vs $0.3 \mathrm{~d}^{-1}$ in the control). Limitation of Synechococcus spp. by inorganic elements, especially $\mathrm{P}$, has already been observed in coastal waters (Vaulot et al. 1996, Schlüter 1998). Still, in the absence of detectable inorganic $\mathrm{N}$ and $\mathrm{P}$ concentrations, Synechococcus spp. were favoured compared to eukaryotes, probably because of (1) its higher surface/volume ratio due to its smaller size (Raven 1986), and (2) a higher affinity for inorganic nutrients (Dolan et al. 1996, Ikeya et al. 1997). Conversely, Synechococcus spp. should have lower affinity for inorganic nutrients than smaller picobacteria (Currie \& Kalff 1984, Raven 1986). However, Ikeya et al. (1997) pointed out that Synechococcus spp. can maintain a high growth rate at nanomolar concentrations through a high-affinity nutrient-uptake system, and is clearly favoured because of its autotrophic abilities. This could explain why, in the absence of nutrient addition, the abundance of Synechococcus spp. increased compared to that of heterotrophic bacteria that were also limited by $\mathrm{C}$. The imbalance between growth and grazing of Synechococcus spp. that resulted in net population increase could be due to the inability of grazers to respond to the high growth rate of Synechococcus spp. (Agawin et al. 1998), but also to the fact that Synechococcus spp. is not a favoured prey for heterotrophic flagellates (Caron et al. 1991, Guillou et al. 2001). Finally, Synechococcus spp. may be little affected by viruses (Waterbury \& Valois 1993).

Daily $\mathrm{N}$ and $\mathrm{P}$ addition was beneficial to all autotrophs so that autotrophic biomass was higher in this enclosure than that of heterotrophs on Day 6 (120 vs $109 \mu \mathrm{gC} \mathrm{l}^{-1}$, respectively). The abundance of most autotrophic populations displayed a bell-shaped pattern, with a maximum at mid-experiment. During the first phase, autotrophic production increased (as a consequence, oxygen concentration was higher in the $+\mathrm{N}+\mathrm{P}$ enclosure); during the second phase, the grazer community probably reacted to this increase. This was particularly clear from both heterotrophic nanoflagellate and ciliate counts (H. Havskum et al. unpubl. data, 
Perez et al. unpubl. data). Net growth rates of eukaryotic populations (i.e. $0.32,0.46,0.41$ and $0.7 \mathrm{~d}^{-1}$ for the cryptophytes, Euk1, 2 and 3 respectively) fell into a 2-fold range, but were comparable to that of Synechococcus spp., suggesting a good efficiency in using high nutrient concentrations and a limited impact of grazers and/or viruses, at least at the beginning of population growth. In contrast to autotrophs, heterotrophic bacterial populations only increased slightly in response to $+\mathrm{N}+\mathrm{P}$ addition, most likely because of DOC limitation (see below). At first sight, there was only a weak variation in the abundance of free pelagic viruses between this enclosure and the control, suggesting that viruses are little affected by changes in the autotrophic compartment and may be more related to the heterotrophs. However, the slight increase in the higher DNAfluorescing V-I particles that followed (with a $2 \mathrm{~d}$ lag) that of the eukaryotes could suggest that V-I are indeed infectious to eukaryotes as suggested above, and that $+\mathrm{N}+\mathrm{P}$ favoured the production of eukaryotic lytic viruses (Wilson et al. 1998). It was not possible from our data to verify this assumption, which should be considered with caution until further investigation.

Addition of glucose alone led to very similar patterns for all communities. Virtually no change occurred during the first week, followed by a slight increase or no change for the second period. In particular, the fact that heterotrophic bacteria remained at constant levels strongly suggests that carbon was not the sole limiting factor for their growth and that inorganic nutrients were also involved. The most striking effect of carbon addition alone compared to the control was the absence of increase in Synechococcus spp., probably because, when glucose was added, heterotrophic bacteria could outcompete Synechococcus spp. in the use of the very low concentration of inorganic nutrient present in the enclosure. This assumption is in agreement with the lower affinity of Synechococcus spp. for inorganic nutrients than picobacteria when $\mathrm{C}$ is available. In our case, it is likely that predation pressure equalled population growth. These results are in agreement with the idealised food-web model proposed by Thingstad et al. (1999) based on heterotrophic bacteria, cyanobacteria and phototrophic eukaryotes with 1 distinct predator for each of these groups. In Thingstad's model, the sum of the biomass of cyanobacteria and of predators on heterotrophic bacteria is invariant and does not depend on what limits bacterial growth rate (Thingstad et al. 1999). Switching from C-limitation to mineral nutrient limitation, as done here by adding a surplus of glucose, is predicted to shift the biomass distribution: cyanobacteria decrease and heterotrophic flagellates preying on heterotrophic bacteria increase (Thingstad et al. 1999). Indeed, a net increase in the amount of heterotrophic nanoflagellates was recorded during our experiment (Perez et al. unpubl. data).

The addition of both inorganic and organic nutrients induced the most important changes inside the microbial community. Both auto- and heterotrophic groups competed for the available resources. The addition of $+\mathrm{N}+\mathrm{P}+10 \mathrm{C}$ was not followed by an immediate increase in picobacteria abundance, and the most important response was registered for larger heterotrophic cells and cryptophytes. Large elongated bacteria were only detected in this enclosure, and therefore clearly required both organic and inorganic nutrients. They were probably not the result of growth of smaller cells, since such large bacteria were already detected by EFM (in very low numbers) at the beginning of the experiment. This opportunistic population displayed higher net growth rate than picobacteria, suggesting that it could be a better competitor at high nutrient concentrations and more resistant to grazing by fast-growing nanoflagellates (Caron et al. 1999). Its rapid disappearance around Day 5 was probably the result of a virus-induced cell lysis or of strong grazing pressure by larger bacterivores such as ciliates. During this first week, autotroph increase was very limited and ceased abruptly, most probably because of the strong grazing pressure from both nanoflagellates and ciliates, which increased markedly in the same period (Perez et al. unpubl. data). Compared to the other eukaryotes, cryptophyte abundance increased markedly in response to $+\mathrm{N}+\mathrm{P}+10 \mathrm{C}$ addition, suggesting a very different strategy for growth. Their heterotrophic capacity, via either osmotrophy or phagotrophy (Gervais 1997, Maranger et al. 1998), may give them a competitive advantage over the other autotrophic groups when both inorganic and organic nutrients are available. The faster decrease of cryptophytes in this enclosure compared to the $+\mathrm{N}+\mathrm{P}$ enclosure also suggested that they were rapidly grazed. The weak increase of Synechococcus spp. abundance recorded during the first few days was followed by a

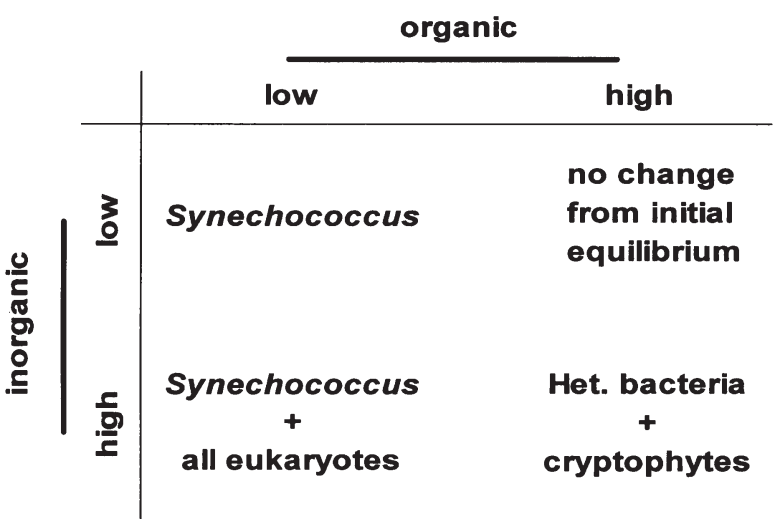

Fig. 7. General scheme of a coastal microbial community competing for inorganic and organic nutrients (see 'Conclusion') 
net decrease, confirming that Synechococcus spp. were outcompeted by bacteria for inorganic nutrients when labile DOC was available (see above). The general increase in virus abundances towards the end of the experiment may have been caused by the nutritionally favourable conditions for virus multiplication. Indeed, it has been suggested that viruses are favoured by high energy input and biological productivity (Bratbak et al. 1994) which, here, could be related to the highest bacterial growth rate. The parallel evolution of both heterotrophic bacteria and viruses suggests that bacterial activity affected viral dynamics which, in turn, could have influenced the structure and diversity of the microbial community (Tuomi et al. 1995).

\section{CONCLUSION}

Understanding the effects of nutrient addition on autotroph vs heterotroph competition within coastal microbial communities is very important to conceptualise the functioning of food webs. Heterotrophic bacteria that are the main recyclers of organic matter in marine systems have often been portrayed as dependent on primary production and protozoan predation. This view has to be enlarged to take into account the shift between mineral nutrient- vs carbon-limited growth of the heterotrophic bacteria. We have shown here that such a shift does not only influence the success of the heterotrophic bacteria themselves, but also influences the success of their trophic neighbours in the food web. The main conclusions have been summarised in Fig. 7. Very schematically, under limiting conditions, smaller cells are clearly favoured. Thus, when both $\mathrm{C}$ and inorganic nutrients are limiting, Synechococcus spp. are favoured because of their autotrophic capacity. Addition of carbon is unfavourable to Synechococcus spp. because they are now outcompeted by bacteria for inorganic nutrient resources. However, heterotrophic bacteria still do not increase compared to the control situation because the initial nutrient stock is low (no additions made) and because bacteria are efficiently grazed. Conversely, when inorganic nutrients alone are added, all autotrophs increase, especially large cells (cryptophytes and picoeukaryotes), which are the best competitors. However, if carbon is added as well, heterotrophic bacteria are 'the winners' along with cryptophytes, probably because of the heterotrophic capacity of the latter.

Acknowledegments. This work was supported by contract MAS3-CT95-0016 (MEDEA) from the European Commission and by a doctoral fellowship from the Ministère de la Recherche et de l'Enseignement Supérieur granted to S.J. We wish to thank Jan C. Bangsholt and Rita Muchitsch from
The International Agency for ${ }^{14} \mathrm{C}$ Determination (Hørsholm, Denmark) for physical and nutrient data. We are grateful to Jean-François Lennon for technical assistance when using the confocal microscope. We are grateful to all the workshop participants for helpful discussion and for the excellent atmosphere that prevailed at the Søminestationen. Three anonymous reviewers and the editor are acknowledged for their suggestions on the manuscript.

\section{LITERATURE CITED}

Agawin NSR, Duarte CM, Agusti S (1998) Growth and abundance of Synechococcus sp. in a Mediterranean Bay: seasonality and relationship with temperature. Mar Ecol Prog Ser 170:45-53

Agawin NSR, Duarte CM, Agusti S (2000) Nutrient and temperature control of the contribution of picoplankton to phytoplankton biomass and production. Limnol Oceanogr 45:591-600

Azam F, Fenchel T, Field JG, Gray JS, Meyer-Reil LA, Thingstad F (1983) The ecological role of water-column microbes in the sea. Mar Ecol Prog Ser 10:257-263

Berg GM, Gilbert PM, Chen CC (1999) Dimension effects of enclosures on ecological processes in pelagic systems. Limnol Oceanogr 44:1331-1340

Bergh O, Borsheim KY, Bratbak G, Heldal M (1989) High abundances of viruses found in aquatic environments. Nature 340:467-468

Bratbak G, Heldal M, Thingstad TF, Riemann B, Haslund $\mathrm{OH}$ (1992) Incorporation of viruses into the budget of microbial C-transfer. A first approach. Mar Ecol Prog Ser 83:273-280

Bratbak G, Thingstad TF, Heldal M (1994) Viruses and the microbial loop. Microb Ecol 28:209-221

Brussard CPD, Thyrhaug R, Marie D, Bratbak G (1999) Flow cytometric analyses of viral infection in two marine phytoplankton species, Micromonas pusilla (Prasinophyceae) and Phaeocystis pouchetii (Prymnesiophyceae). J Phycol 35:941-948

Caron DA, Lin LE, Miceli G, Waterbury JB, Valois FW (1991) Grazing and utilisation of chroococcoid cyanobacteria and heterotrophic bacteria by protozoa in laboratory cultures and a coastal plankton community. Mar Ecol Prog Ser 76: 205-217

Caron DA, Peele ER, Lim LE, Dennett MR (1999) Picoplankton and nanoplankton and their trophic coupling in surface waters of the Sargasso Sea south of Bermuda. Limnol Oceanogr 44:259-272

Cavender-Bares KK, Mann E, Chisholm SW, Ondrusek ME, Bidigare RR (1999) Differential response of Equatorial Pacific phytoplankton to iron fertilization. Limnol Oceanogr 44:237-246

Cole JJ, Findlay S, Pace ML (1988) Bacterial production in fresh and seawater ecosystem: a cross-system overview. Mar Ecol Prog Ser 43:1-10

Currie D, Kalff J (1984) Can bacteria outcompete phytoplankton for phosphorus? A chemostat test. Microb Ecol 10: 205-216

Dolan JR, Thingstad TF, Rassoulzadegan F (1996) Phosphorus transfer between microbial size-fractions in Villefranche Bay (North Western Mediterranean Sea), France, in autumn 1992. Ophelia 41:15-22

Egge JK, Heimdal BR (1994) Blooms of phytoplankton including Emiliania huxleyi (Haptophyta): effects of nutrient supply in different N:P ratios. Sarsia 79:333-348

Gervais F (1997) Light-dependent growth, dark survival, and 
glucose uptake by cryptophytes isolated from a freshwater themocline. J Phycol 33:18-25

Gonzales JM, Sherr EB, Sherr BF (1990) Size-selective grazing on bacteria by natural assemblages of estuarine flagellates and ciliates. Appl Environ Microbiol 56:583-589

Guillou L, Jacquet S, Chrétiennot-Dinet MJ, Vaulot D (2001) Grazing impact of two small heterotrophic flagellates on Prochlorococcus and Synechococcus. Aquat Microb Ecol 26:201-207

Havskum H, Hansen AS (1997) Importance of pigmented and colourless nano-sized protists as grazers on nanoplankton in a phosphate-depleted Norwegian fjord and in enclosures. Aquat Microb Ecol 12:139-151

Havskum H, Riemann B (1996) Ecological importance of bacterivorous, pigmented flagellates (mixotrophs) in the Bay of Aarhus, Denmark. Mar Ecol Prog Ser 137:251-263

Ikeya T, Ohki K, Takahashi M, Fujita Y (1997) Study on phosphate uptake of the marine cyanophyte Synechococcus sp. NIBB 1071 in relation to oligotrophic environments in the open ocean. Mar Biol 129:195-202

Jacquet S, Lennon JF, Marie D, Vaulot D (1998) Picoplankton population dynamics in coastal waters of the NW Mediterranean Sea. Limnol Oceanogr 43:1916-1931

Karl DM (1999) A sea of change: biogeochemical variability in the North Pacific subtropical gyre. Ecosystems 2:181-214

Lee S, Fuhrman JA (1987) Relationships between biovolume and biomass of naturally derived marine bacterioplankton. Appl Environ Microbiol 53:1298-1303

Lee YS, Seiki T, Mukai T, Takimoto K, Okada M (1996) Limiting nutrients of phytoplankton community in Hiroshima Bay, Japan. Water Res 30:1490-1494

Li WKW (1998) Annual average abundance of heterotrophic bacteria and Synechococcus in surface ocean waters. Limnol Oceanogr 43:1746-1753

Li WKW, Platt T (1987) Photosynthetic picoplankton in the ocean. Sci Prog 71:117-132

Maranger R, Bird DF, Price NM (1998) Iron acquisition by photosynthetic marine phytoplankton from ingested bacteria. Nature 396:248-251

Marie D, Brussaard C, Bratbak G, Vaulot D (1999) Enumeration of marine viruses in culture and natural samples by flow cytometry. Appl Environ Microbiol 65:45-52

Marie D, Partensky F, Simon N, Guillou L, Vaulot D (2000) Flow cytometry analysis of marine picoplankton. In: Diamond RA, DeMaggio S (eds) Living colors: protocols in flow cytometry and cell sorting. Springer-Verlag, Berlin, p 422-454

Mullin MM, Sloan PR, Eppley PW (1966) Relationship between carbon content, cell volume, and area in phytoplankton. Limnol Oceanogr 11:307-311

Neveux J, Lantoine F, Vaulot D, Marie D, Blanchot J (1999) Phycoerythrins in the southern tropical and equatorial Pacific Ocean: evidence for new cyanobacterial types. J Geophys Res 104:3311-3321

Olson RJ, Chisholm SW, Zettler ER, Armbrust EV (1990) Pigment, size and distribution of Synechococcus in the North Atlantic and Pacific Ocean. Limnol Oceanogr 35:45-48

Raven JA (1986) Physiological consequence of extremely small size in autotrophic organisms in the sea. Can Bull Fish Aquat Sci 214:1-70

Rivkin RB and 18 others (1996) Vertical flux of biogenic car-

Editorial responsibility: Otto Kinne (Editor),

Oldendorf/Luhe, Germany bon in the ocean: is there food web control? Science 272: 1163-1166

Schlüter L (1998) The influence of nutrient addition on growth rates of phytoplankton groups, and microzooplankton grazing rates in a mesocosm experiment. J Exp Mar Biol Ecol 228:53-71

Simon M, Azam F (1989) Protein content and protein synthesis rates of planktonic marine bacteria. Mar Ecol Prog Ser $51: 201-213$

Søndergaard M, Jensen LM, Ærtebjerg G (1991) Picoalgae in Danish coastal waters during summer stratification. Mar Ecol Prog Ser 79:139-149

Thingstad TF, Heldal M, Bratbak G, Dundas I (1993) Are viruses important partners in pelagic food webs? Trends Ecol Evol 8:209-213

Thingstad TF, Bratbak G, Heldal M, Dundas I (1997) Trophic interactions controlling the diversity in pelagic microbial food webs. In: Martins MT (ed) Progress in microbial ecology, Brazilian Society for Microbiology, Rio de Janeiro, p 107-114

Thingstad TF, Zweifel UL, Rassoulzadegan F (1998) Indications of P-limitation for heterotrophic bacteria and phytoplankton in the NW Mediterranean summer surface waters. Limnol Oceanogr 43:88-94

Thingstad TF, Perez M, Pelegri S, Dolan JR, Rassoulzadegan F (1999) Trophic control of bacterial growth in microcosms containing a natural community from northwest Mediterranean surface waters. Aquat Microb Ecol 18: $145-156$

Tuomi P, Fagerbakke KM, Bratbak G, Heldal M (1995) Nutritional enrichment of a microbial community: the effects on activity, elemental composition, community structure and virus production. FEMS Microbiol Ecol 16:123-134

Vaulot D (1989) CytoPC: processing software for flow cytometric data. Signal Noise 2:8

Vaulot D, Lebot N, Marie D, Fukai E (1996) Effect of phosphorus on the Synechococcus cell cycle in surface in Mediterranean waters during summer. Appl Environ Microb 132:265-274

Verity PG, Robertson CY, Tronzo CR, Andrews MG, Nelson JR, Sieracki ME (1992) Relationships between cell volume and the carbon and nitrogen content of marine photosynthetic nanoplankton. Limnol Oceanogr 37:1434-1446

Waterbury JB, Valois FW (1993) Resistance to co-occuring phages enables marine Synechococcus communities to coexist with cyanophages abundant in seawater. Appl Environ Microbiol 59:3393-3399

Waterbury JB, Watson SW, Valois FW, Franks DG (1986) Biological and ecological characterisation of the marine unicellular cyanobacterium Synechococcus. Can Bull Fish Aquat Sci 214:71-120

Wilson WH, Turner S, Mann NH (1998) Population dynamics of phytoplankton and viruses in a phosphate-limited mesocosm and their effect on DMSP and DMS production. Estuar Coast Shelf Sci 46:49-59

Ypma JE, Throndsen J (1996) Seasonal dynamics of bacteria, autotrophic picoplankton and small nanoplankton in the inner Oslofjord and the Skagerrak in 1993. Sarsia 81: $57-66$

Submitted: October 18, 2000; Accepted: August 14, 2001

Proofs received from author(s): February 12, 2002 